\title{
HOUSEHOLDS' DEMAND FOR GROUNDWATER CONSERVATION: THE CASE OF IRRIGATION PRACTICES IN KOMBOLCHA DISTRICT, EASTERN ETHIOPIA
}

\author{
Saleamlak Fentaw ${ }^{1}$, Alem Mezgebo ${ }^{2}$
}

\begin{abstract}
Summary
Ground water degradation is the problem, and its management is curial for sustaining the benefit from the resource. To maintain the resource we have to have full information about the value of the resource conservation. Therefore, in this study a contingent valuation survey was conducted in Kombolcha district to elicit households 'willingness to pay for groundwater conservation. A sample of 394 households was randomly selected, and interviewed. However, after checked for sample selection bias 4 protest bidders were excluded from the data set. Tobit model was applied to determine the factors affecting willingness to pay. The descriptive analysis shows that about $82 \%$ of the respondents reported that the groundwater has being degraded due to population pressure, deforestation, soil degradation, agricultural expansion and climatic change. The mean willingness to pay was computed at 60.63 ETB with the total willingness to pay of 1,689,576.21 per annum. The study determined that monthly income, educational level, total farm land holding, total family size, perception and tropical livestock unit were variables that have significant effect on households' willingness to pay. Thus, socio-economic variables should also be considered while designing water related projects at household level.
\end{abstract}

Keywords: Contingent Valuation Method, Groundwater conservation, Tobit model, Willingness to Pay

JEL: $Q 25, Q 50, Q 51, Q 59$

1 Saleamlak Fentaw, MSc., College of Agriculture and Environmental Science, School of Agricultural Economics and Agribusiness, Haramaya University, Ethiopia, Email: salefen@, gmail.com; mobile: +251-913584558

2 Alem Mazgebo, College of Agriculture and Environmental Science, School of Agricultural Economics and Agribusiness, Haramaya University, Ethiopia; mobile: +251-966211315, Email: adeway12@gmail.com (Corresponding author)

EP 2018 (65) 1 (173-185) 


\section{Introduction}

Groundwater is water located below the earth's surface in the saturated zone unlike the surface water (Siebert et al., 2010). It is a valuable renewable natural resource, and its availability depends on economic activities (Emerton and Bos, 2004). Globally, groundwater is an important resource for irrigation practices and hence livelihoods and food security of billions of people (Morris et al., 2003). Groundwater aquifers have the potential to be used for anthropogenic carbon dioxide sequestration (Malanson, 1993; FAO, 2003), and indirectly regulate soil erosion (Malanson, 1993). Intensive groundwater uses for irrigation has given rise to satisfy social and economic benefits. However, the poor management and intensive groundwater use has all too often been the causes of groundwater degradation. Groundwater degradation directly and indirectly affected economic activities. The increased pressure on groundwater results in wells drying up and conflict between users (Morris et al., 2003). Moreover, only rich farmers can afford to a reliable source of water; and the poorer sectors of society are likely to be the hardest hit as they are the most vulnerable to ecosystem changes. Generally, declining groundwater levels have an impact particularly in the developing world, and forcing women and children to walk long distances to take water resource (FAO, 2003).

Groundwater management is crucial for poverty alleviation, environmental conservation as well as sustaining the benefit from the resource. There has been a growing concern by policy makers, interest groups and the public for the management of groundwater. In order to manage groundwater, among others, more reliable information on the economic value of groundwater conservation is crucial. This study therefore, tried to estimate the economic values of groundwater conservation using contingent valuation method (CVM). A respondent was introduced to a hypothesized market scenario and a willingness to pay (WTP) value. The study provides valuable information on the value of groundwater conservation of Kombolcha district to decision makers and agricultural water users that are affected by the degradation of the resource. It is believed that the study plays a key role in formulation of a successful groundwater policy.

\section{Measuring Welfare Change}

The values of environmental resources (like groundwater resource) are measured using its effects on human welfare (Mitchell and Carson, 1989). A weaker, but perhaps ethically more neutral, criteria for welfare measure is Pareto improvement. In Pareto improvement a policy change makes one or more persons better off without making at least one other person worse off (Haab and McConnell, 2002).

Change in environmental goods (from statuesque to improvement) can affect individual's welfare through changes in prices they pay for private inputs and goods, and the quantities of non-marketed environmental goods. This welfare changes can be measured using ordinary consumer's surplus, which holds income constant but not the level of utility. According to Hicks (1943) the welfare changes can also be measured using compensating surplus, compensating variation, equivalent variation 
and equivalent surplus. Compensating variation and compensating surplus measure the gains or loss from environmental goods and services, and hold utility constant at the initial level. However, equivalent variation and equivalent surplus measure welfare change and hold utility constant at some specified alternative level. Generally, these four welfare measures involve either payment or compensation to maintain utility at the specified level (Randall and Stall (1980), cited in Mitchell and Carson 1989). If the proposed change is welfare increasing through changes in the quantity of environmental goods, which is the focus of this study, the appropriate welfare measure is the compensating surplus. This measure can be interpreted as the consumer's WTP in order to gain the quantity increase and still maintain their initial utility level (Mitchell and Carson 1989).

In Hicksian demand curve, the demand function for the public good requires accurate market data. But, it is very difficult to obtain accurate market data therefore, contingent valuation method, which requires the creation of hypothetical market scenario that is similar to actual market situation for groundwater conservation was used. From this method we can generate the WTP data without having to estimate the actual demand curve. This concept can be further emphasized from the relationship between the expenditure function and Hicksian compensated surplus measure. According to Haab and McConnell (2002), the expenditure function that provides the theoretical structure for welfare estimation is specified as:

$\mathrm{y}=\mathrm{e}(\mathrm{p}, \mathrm{q}, \mathrm{u})=\min \_\mathrm{x}\{\mathrm{p} \cdot \mathrm{x} / \mathrm{u}(\mathrm{x}, \mathrm{u}) \geq \mathrm{u}\}$

Where: $\mathrm{y}$ is the minimum amount of income needed to maintain utility level given the price and public good vectors; $q$ is the vector of environmental goods; $\mathrm{p}$ is a vector of prices; $\mathrm{u}$ is level of utility when $\mathrm{u}=\mathrm{V}(\mathrm{p}, \mathrm{q}, \mathrm{y})$; $\mathrm{x}$ is the vector of private goods and $\mathrm{y}$ is income. Let $\mathrm{p}_{0}, \mathrm{q}_{0}, \mathrm{u}_{0}, \mathrm{y}_{0}$ represent some initial level of those respective arguments and $\mathrm{p}_{1}, \mathrm{q}_{1}, \mathrm{u}_{1}, \mathrm{y}_{1}$ represent some succeeding levels. The derivative of the expenditure function with respect to price gives the Hicksian or utility-constant demand. We can represent the compensation surplus by:

$W T P=C S=\left[e\left(p_{0}, q_{0}, u_{0}\right)\right]-\left[e\left(p_{0}, q_{1}, u_{0}\right)\right]$

$q_{1}$ is preferred to $q_{0}$ for proposed new project brings welfare gain. In this case, the compensated surplus (CS) measure tells us the consumers" WTP for welfare gain. WTP is the amount of income an individual would give up to make him indifferent between the original state: income at $y$ and the public good at $\mathrm{q}_{0}$ and the revised state: income reduced to $y-W T P$ and the public good increased to $\mathrm{q}_{1}$. Contingent valuation is capable of obtaining the appropriate Hicksian measure for a proposed change in the public good (Mitchell and Carson 1989). It can be viewed as a way of estimating the change in the expenditure function (Haab and McConnell 2002). This study determines the value of groundwater conservation using the concept of WTP. 


\section{Methodology}

\section{Description of the study area}

The study was conducted in Kombolcha district located about $514 \mathrm{kms}$ south east of Addis Ababa. The district is having an area of $446.61 \mathrm{~km}^{2}$, and found in the northern part of East Hararghe zone. The district falls under Woina dega (74\%) and Kola (26\%) agro-climatic zones. The annual rainfall and temperature of the district ranges from $600 \mathrm{~mm}$ to $900 \mathrm{~mm}$ and $18^{\circ} \mathrm{c}$ to $23^{\circ} \mathrm{c}$, respectively. Based on the 2007 population and housing census of Ethiopia, the district has a total population of about 140,769 (FDREPCC, 2008). The livelihood of the population typically depends on croplivestock mixed farming system. The district's farming economy is characterized by small and fragmented land holdings with an average of 0.25 hectare. The district is one of the major producers of vegetables including potato, onion, cabbage, beet root, tomato, and lettuce using irrigation water.

\section{Sampling techniques and data collection methods}

A two-stage sampling technique was used to select sample respondents. In the first stage, 3 rural kebeles were purposively selected out of the 19 kebeles based on identified as they are more attached to the water resource. These sample kebeles include Bilisumma, Kerensa and Walta Lamaan. In the second stage, proportionally with population percentage of these 3 kebeles, a total of 394 households were selected using simple random sampling techniques. Both secondary and primary data were used for this study. The primary data were collected using face to face interviews with the heads or working members of the households. A CVM method in the form of open ended elicitation format was used to elicit households' WTP for groundwater conservation.

\section{Data analysis}

The survey data was analyzed using descriptive statistics and econometric models. Tobit econometric model was used to analyze the determinants of WTP for groundwater conservation. This model has an advantage over other discrete choice models (Linear probability model, logistic, and probit) in that, it reveals both the probability and the maximum WTP of the respondents. In discrete choice models like probit and logit model the dependent variable $\left(\boldsymbol{y}_{i}^{*}\right)$ is not observed, what we observe is the dummy variable. However, in Tobit model the dependent variable, or the WTP, is partially observed and the dependent variable $\left(\boldsymbol{y}_{i}^{*}\right)$ assumes zero values for a substantial part of the sample. That is, $\boldsymbol{y}_{i}^{*}$ is observed if $\boldsymbol{y}_{i}^{*}>0$ and is not observed if $\boldsymbol{y}_{i}^{*} \leq \mathbf{0}$. If $\mathrm{y}^{*}$ and $\mathbf{x}_{\mathrm{i}}$ were observed for everyone in the population, we could use standard regression methods (ordinary least squares (OLS)) (Maddala, 1992). However, in this study since we deal with maximum WTP for groundwater conservation which is partly observed, we employed Tobit model. The censored regression (Tobit) models generally apply when the variable to be explained is partly continuous. According to Maddala (1997) the equation for Tobit model is constructed as: 
$y_{i}^{*}=\beta x_{i}+\varepsilon_{i}$

$y_{i}= \begin{cases}y_{i}^{*}=\beta x_{i}+\varepsilon_{i} & \text { if } y_{i}^{*}>0 \\ 0 & \text { if } y_{i}^{*} \leq 0\end{cases}$

where: $\mathrm{y}_{\mathrm{i}}^{*}$ is latent or unobserved willingness to pay for groundwater conservation; $\mathrm{y}_{\mathrm{i}}$ is a household's actual maximum willingness to pay; $x_{i}$ is vector of explanatory variables; $\beta$ is a parameter vector common to all households; $\alpha$ is the intercept; and assuming the random error $\varepsilon_{i}$ is independent and normally distributed across respondents, $\varepsilon_{\mathrm{i}} \sim \operatorname{NID}\left(0, \sigma^{2}\right)$. Some of the households interviewed did not have any WTP, whereas, some of them had WTP for groundwater conservation. For those not undertaking WTP is zero in Tobit model the WTP is a random variable and has probability distribution, and it is possible to determine each observations probability.

$p\left(y_{i}=0\right)=p\left(\varepsilon_{i}<\beta \mathrm{x}_{\mathrm{i}}\right)=1-\mathrm{F}\left(\beta \mathrm{x}_{\mathrm{i}}\right)$

$p\left(y_{i}>0\right)=1-p\left(y_{i}=0\right)=\mathrm{F}\left(\beta \mathrm{x}_{\mathrm{i}}\right)$

Where $\mathrm{p}$ is probability distribution and $\mathrm{F}\left(\beta \mathrm{x}_{\mathrm{i}}\right)$ is cumulative density function

The model parameters can be estimated by maximizing the Tobit likelihood function of the following form.

$L=\prod_{y^{*}>0} \frac{1}{\sigma} f \ln \left(\frac{y_{i}-\beta x}{\sigma}\right) \prod_{y^{*} \leq 0} \frac{1}{\sigma} F\left(\frac{-\beta x}{\sigma}\right)$

$\mathrm{f}$ and $\mathrm{F}$ are the density probability function and cumulative distribution function of $y_{i}^{*}$ respectively. $\prod_{y^{*}>0}$ means that the product over those i for which $y^{*}>0$, and $\prod_{\substack{* \\ y^{*} \leq 0}}$ means the product over those i for $y^{*} \leq 0$.

The Tobit coefficients do not directly give the marginal effects of the associated explanatory variable on the dependent variable. But their signs show the direction of change in probability of WTP as the respective explanatory variables changes. Therefore, it is not reasonable to interpret in the same way as the one interprets coefficients in an uncensored linear model (Johnston and Dinardo, 1997). Hence, we should estimate the marginal effect of the Tobit model. According to, Long (1997) and McDonald and Maffitt (1980) to identify the effects of explanatory variables on the probability of WTP, conditional and unconditional WTP the following techniques could be used.

The marginal effect of an explanatory variable on the expected value of the dependent variable was estimated by:

$\frac{\partial E\left(y_{i}\right)}{\partial x_{i}}=F(z) \beta$ 
The change in the probability of willingness to pay for groundwater conservation as explanatory variable $X_{i}$ changes was estimated by:

$\frac{\partial F(z)}{\partial X_{i}}=f(z) \frac{\beta}{\delta}$

Similarly, the change in the probability of willingness to pay with respect to a change in explanatory variable among willing respondents was estimated by:

$\frac{\partial E\left(y_{i} / y_{i}^{*}>0\right)}{\partial X_{i}}=\beta\left[1-Z \frac{f(z)}{F(z)}-\left(\frac{f(z)}{F(z)}\right)^{2}\right\rceil$

Where, $z=\frac{x \beta}{\delta}, F(z)$ is the cumulative normal distribution of $\mathrm{Z}, \mathrm{f}(\mathrm{z})$ is the value of the derivative of the normal curve at a given point ( that is, unit normal density), $\mathrm{Z}$ is the Z-score for the area under the normal curve, $\beta$ is the vector of Tobit maximum likelihood estimates and $\delta$ is the standard error of the error term.

\section{Result and Discussion}

\section{Characteristics of sampled households}

A total of 394 sampled households were interviewed. However, 4 respondents were protested zero bidders and after checked for sample selection bias they were excluded from the data set. Of the total 390 respondents, 52\% were males while $48 \%$ were female respondents. The age of these sampled respondents' ranges from 16 to 78 years with an average of 37.57 years old. The survey results also showed that $70 \%$ of the respondents were married and the rest 30\% were single. A total number of 2552 persons were recorded with a minimum of 2 persons and a maximum of 12 persons per households. On average, about 7 persons per household were recorded which was above the national average of 4.7 persons (FDREPCC, 2008). This is because the households could have more than one wife. The result on the status of the respondents showed that $69 \%$ of the respondents were head of the households, and the rest $31 \%$ were working member of the households. Educational attainment is another parameter considered in our empirical models. The educational status of the sampled respondents ranges from zero (illiterate) to $10+3$ years of schooling with an average of about 6 years of schooling. The total farm land holding of the sampled households was also estimated at 136.23 ha with average cultivated farm size per household of 0.35 ha (see Table 1). This indicated that the average farm size of the study area is lower than the national average of 0.8 ha (CSA, 1995).

Table 1. Socio-economic characteristics of the sample households

\begin{tabular}{|l|l|l|l|l|}
\hline Variables & \multicolumn{1}{|c|}{ Mean } & \multicolumn{1}{c|}{ Std. Dev. } & \multicolumn{1}{c|}{ Min } & \multicolumn{1}{c|}{ Max } \\
\hline Maximum willingness to pay & 60.63 & 42.80 & 0 & 200 \\
\hline Household income & 1641.33 & 1342.40 & 258.33 & 5850 \\
\hline
\end{tabular}




\begin{tabular}{|l|l|l|l|l|}
\hline Age & 37.57 & 15.60 & 16 & 78 \\
\hline Sex & 0.521 & 0.50 & 0 & 1 \\
\hline Marital status & 0.7 & 0.46 & 0 & 1 \\
\hline Educational level & 5.89 & 3.54 & 0 & 13 \\
\hline Status of the respondents & 0.69 & 0.46 & 0 & 1 \\
\hline Total family size & 6.544 & 2.68 & 2 & 12 \\
\hline Tropical livestock unit(TLU) & 1.86 & 0.70 & 1.56 & 3.87 \\
\hline Total farmland holding & 0.349 & 0.27 & 0.2 & 1.83 \\
\hline Perception & 0.815 & 0.39 & 0 & 1 \\
\hline
\end{tabular}

Source: own survey, 2017

Major sources of income of the households' are from on farm activities primarily from production of crops and livestock production. The total monthly income of these households was computed at 495,117.56 ETB. On the other hand, the monthly income of the households obtained from off farm activities were also computed at ETB 145,000. The fact that off-farm incomes contribute smallest to the total family income, it explains that most of the surveyed household can rely mainly on agricultural activities with relatively narrow landholding size for their livelihood. Data related to livestock owned by the respondents was also collected in terms of TLU ${ }^{3}$. On average the survey result show that 1.86 TLU with a minimum of 1.56 and maximum of 3.87 was recorded per households (Table 1).

\section{Causes and effects of groundwater degradation}

The groundwater has been degraded to satisfy the demands of the ever increasing population for agricultural production. About $82 \%$ of the respondents were known the goods to be valued properly. They have an experience of using the resource for irrigation practices. The respondents reported that the availability of groundwater is decreasing from time to time. This shows that the depth of the water table is increase. The reasons attributed to the problem were population pressure, deforestation, soil degradation, agricultural expansion and climatic change. The result indicated that population pressure was the main causes of groundwater degradation. Therefore, the government should create awareness on family planning of the local people. On the other hand, about $18 \%$ of the respondents did not perceive the problems of groundwater degradation (Table 2).

Table 2. Causes of groundwater degradation

\begin{tabular}{|l|c|c|}
\hline Causes & Number of households & Percent \\
\hline Population pressure & 82 & 21.03 \\
\hline Deforestation & 60 & 15.38 \\
\hline Soil degradations & 78 & 20 \\
\hline Agricultural expansion & 65 & 16.67 \\
\hline
\end{tabular}

3 Conversion factors used in estimation of tropical livestock unit (TLU) were Donkey $=0.7$; Cow, Bulls and $\mathrm{Ox}=1$; Calf $=0.25$; Sheep and Goats $=0.13$; Chicken $=0.013$ and Camel $=1.25$

EP 2018 (65) 1 (173-185) 


\begin{tabular}{|l|c|c|}
\hline Causes & Number of households & Percent \\
\hline Climate change & 35 & 8.97 \\
\hline None & 70 & 17.95 \\
\hline Total & 390 & 100 \\
\hline
\end{tabular}

Source: Survey result, 2017

They pay nothing for the water resource except the withdrawal and digging cost. This is because the wells used for irrigation practices is owned as private property. They bought motor pump on average estimated at birr 9000. The fuel used to pump the water was 1.5 liter per hour. The survey result shows that the price of the fuel at the time of the survey was 25 birr per liter. The price of the fuel is above the price set by the Ethiopian government, and its shows that there was a black market.

Seven effects of groundwater degradation perceived by the respondents were also identified and described: (1) health problem (2) delay in household chores (3) food shortage (4) low income, and (5) enhanced climate change. In particular, $19.23 \%$ of the respondents indicated that health problem was the effects of groundwater degradation. About $20.51 \%$ of the respondents' reported that they earned low income (Table 3 ).

Table 3. Effects of groundwater degradation

\begin{tabular}{|l|c|c|}
\hline Effects & Number of households & Percent \\
\hline Health problem & 75 & 19.23 \\
\hline Delay in household chores & 60 & 15.38 \\
\hline Food shortage & 78 & 20.00 \\
\hline Low income & 80 & 20.51 \\
\hline Enhanced climate change & 27 & 6.92 \\
\hline None & 70 & 17.95 \\
\hline Total & 390 & 100 \\
\hline
\end{tabular}

Source: Survey result, 2017

Protection measures were also elicited from the aware respondents for possible improvement of the degraded groundwater. A majority of the respondents suggested that strong government regulation, soil and water conservation, tree planting and training groundwater users are among the protection measures (Table 4).

Table 4. Perception on protection measures of groundwater degradation

\begin{tabular}{|l|c|c|}
\hline Protection measures & Number of households & Percent \\
\hline Strong government regulation & 58 & 14.87 \\
\hline Soil and water conservation & 87 & 22.31 \\
\hline Tree planting & 95 & 24.36 \\
\hline Training groundwater users & 80 & 20.51 \\
\hline None & 70 & 17.95 \\
\hline Total & 390 & 100 \\
\hline
\end{tabular}

Source: Survey result, 2017 


\section{Households WTP for groundwater conservation}

The result shows that $75.38 \%$ of the sampled households were willing to pay for groundwater conservation. Using open ended elicitation format the mean WTP were estimated at 60.63 ETB per year per household for ten years. The willing respondents were also asked to point out their reasons for maximum WTP in ETB. The respondents provided different reasons for their maximum WTP. About $48.97 \%$ of the respondents reported that they could not afford more than what they stated because of inadequate income. While, $13.33 \%$ and $13.08 \%$ reported that the amount they decided to pay was satisfactory, and other should pay respectively. However, about $24.62 \%$ of the sample respondents' were not willing to pay for groundwater conservation.

\section{Factors affecting households' WTP}

Estimate of the parameters of the variables expected to affect willingness to pay for groundwater conservation are shown in Table 5 . The dependent variable is partly a continuous variable that individuals respond as maximum willingness and ability to pay for the improvement service recalling the benefits expected out of it. A total of 10 explanatory variables were considered in the econometric analysis, out of which 6 explanatory variables were statistically significant. The other 4 explanatory variables are insignificant effect on the amount of WTP for groundwater conservation.

Table 5. The Tobit model estimation results of households' WTP

\begin{tabular}{|c|c|c|c|}
\hline \multicolumn{4}{|c|}{ Dependent variable: Maximum Willingness to Pay; 390 observations } \\
\hline Explanatory Variables & Coef. & Std.Err. & t-value \\
\hline Households income & $0.008 * * *$ & 0.002 & 3.87 \\
\hline Age & -0.235 & 0.204 & -1.15 \\
\hline Sex & -0.53 & 5.65 & -0.09 \\
\hline Marital status & 2.927 & 8.04 & 0.36 \\
\hline Education & $2.213 * * *$ & 0.801 & 2.76 \\
\hline Respondents status & 0.308 & 8.07 & 0.04 \\
\hline Total family size & $2.412 * *$ & 1.08 & 2.23 \\
\hline Tropical livestock unit & $11.56^{* * *}$ & 3.97 & 2.91 \\
\hline Total farm land holding & $20.43 * *$ & 9.74 & 2.1 \\
\hline Perception & $6.61^{* *}$ & 6.98 & 0.95 \\
\hline Cons & -5.17 & 16.45 & -0.31 \\
\hline \multicolumn{4}{|l|}{ Log likelihood $=-1676.30$} \\
\hline \multicolumn{4}{|l|}{ LR $\operatorname{chi} 2(10)=40.87$} \\
\hline \multicolumn{4}{|c|}{ Prob $>$ chi $2=0.000$} \\
\hline \multicolumn{4}{|c|}{ Obs. summary: 96 left censored observations at $\operatorname{maxwtp}<=0$} \\
\hline \multicolumn{4}{|c|}{294 uncensored observations } \\
\hline \multicolumn{4}{|c|}{0 right-censored observations } \\
\hline
\end{tabular}

** significant at 5\%; *** significant at 1\% significance levels (survey result, 2017)

However, the interpretation of the censored regression model is not straightforward. That is, the marginal effects cannot be adequately explained from the estimated coefficients 
of the Tobit model. Therefore, for interpretation of the Tobit model this paper report three sets of marginal effects: (1) the effect on the probability of a positive WTP, (2) the effect on conditional WTP, and (3) the effect on unconditional WTP for groundwater conservation. To be more specific, households' monthly incomes have positive and significant association with the households WTP for groundwater conservation. That is, when the income of the household increase by one birr, it would increase the probability of willingness of a household to pay by about $0.004 \%$. Besides, when income of the household increase by one birr their willingness to pay would increase, on average, by about 0.007 ETB for all observation and 0.005 ETB for willing respondents', ceteris paribus. This shows that groundwater resource is a normal economic good whose demand changes in the direction of income change. Respondents with higher education levels were more likely to state positive WTP, and on average, they actually stated higher conditional and unconditional WTP than respondents with lower educational levels. This result suggests that investing in education of people might help to improve the degraded environmental resource like groundwater. The marginal effect of the result shows that the respondent being educated, the probability of willingness to pay increases by $0.2 \%$. Also, as the years of education increases by one year, the amount of cash the household is willing to pay for groundwater conservation increase by 1.88 birr for the whole sample of study, and 1.41 birr for the willing respondents, ceteris paribus. The variables perception has positive and significant effect on the amount of WTP. A unit changes in perception from 0 (unperceived) to 1 (perceived) the probability being willing to pay increases by $2.86 \%$. That is, the marginal effect result shows that a unit changes from 0 to 1 the willingness to pay increased by 5.67 birr and 4.3 birr for the whole and willing respondents respectively, ceteris paribus (Table 6).

Table 6. Marginal effects of the explanatory variable on the amount of willingness to pay

\begin{tabular}{|l|c|c|c|}
\hline Explanatory Variables & $\begin{array}{c}\text { Change in probabilities } \\
\text { as explanatory variable } \\
\text { changes }\end{array}$ & $\begin{array}{c}\text { Change among } \\
\text { individuals who are } \\
\text { willing to pay }\end{array}$ & $\begin{array}{c}\text { Change among } \\
\text { the whole }\end{array}$ \\
\hline Households income & 0.00004 & 0.005 & 0.0069 \\
\hline Age & -0.00106 & -0.15 & -0.1994 \\
\hline Sex & -0.00239 & -0.339 & -0.4499 \\
\hline Marital status & 0.01338 & 1.86 & 2.478 \\
\hline Education & 0.00199 & 1.41 & 1.879 \\
\hline Respondents status & 0.00139 & 0.197 & 0.2611 \\
\hline Total family size & 0.0109 & 1.54 & 2.048 \\
\hline Tropical livestock unit & 0.0522 & 7.39 & 9.814 \\
\hline Total farm land holding & 0.0923 & 13.06 & 17.34 \\
\hline Perception & 0.0286 & 4.3 & 5.671 \\
\hline
\end{tabular}

Source: own survey, 2017

\section{Aggregate WTP for groundwater conservation}

An important issue related to the measurement of welfare using WTP is aggregation of benefit (Alemu, 2000). According to Mitchell and Carson (1989) there are four important 
issues to be considered regarding sample design and estimating a valid aggregation of benefits: population choice bias, sampling frame bias, none response bias and sample selection bias. Random sampling method was used in this study using a list of households. Face to face interview methods was used and protest zero responses were excluded from the analysis and expected protest zeros was accounted in the estimation of the total aggregate benefit of groundwater conservation in this paper. Hence, none of the above biases was expected in this study. Mean WTP was used as a measure of aggregate value of groundwater conservation in this study. The mean is perhaps better than the median since the good dealt with is not a pure public good (Alemu, 2000), as there are purely private benefits from groundwater conservation measures. As it is indicated in Table 7 below, the aggregate WTP was calculated by multiplying the mean WTP by the total number of households in the population. Following this, the aggregate WTP for groundwater conservation was computed at 1,689,576.21 birr per year for ten years.

Table 7. Aggregate Benefits of groundwater conservation

\begin{tabular}{|c|c|c|c|c|}
\hline $\begin{array}{c}\text { Total } \\
\text { households } \\
(\mathbf{Y})\end{array}$ & $\begin{array}{l}\text { Expected households to have } \\
\text { a protest zeros }(\mathbf{X})^{\mathbf{4}}\end{array}$ & $\begin{array}{c}\text { Expected } \\
\text { households with } \\
\text { valid responses } \\
(\mathbf{Z})^{\mathbf{5}}\end{array}$ & $\begin{array}{c}\text { Mean } \\
\mathbf{W T P}^{\mathbf{6}}\end{array}$ & $\begin{array}{c}\text { Aggregate Benefit } \\
\text { (in Birr) }^{\mathbf{7}}\end{array}$ \\
\hline 28154 & 287 & 27867 & 60.63 & $1,689,576.21$ \\
\hline
\end{tabular}

Source: Own survey, 2017

\section{Conclusion and Recommendations}

The purpose of this study was to assess the economic value of groundwater conservation using CVM. The descriptive analysis shows that $82 \%$ of the respondents reported that the availability of groundwater is decreasing from time to time, and the reasons attributed to the problem were population pressure, deforestation, soil degradation and agricultural expansion and climatic change. In order to improve the availability of groundwater policy makers should encourage and provide technical advice to households who are planting and maintaining tree resource, and practicing soil and water conservation. The results of the study on willingness to pay showed that the households were willing to pay for groundwater conservation. The annual mean WTP value of households was computed at 60.63 birr per year. Small respondents were recorded as protest zero, and imply that contingent valuation method is appropriate method to value groundwater

$44(1.02 \%)$ of 394 sampled households were protest zeros. We excluded those protest zeros from further analysis after we have tested for sample selection bias. So X is the expected number of households which are expected to protest for the proposed project. It is calculated by the percentage of sampled protest zeros $(1.02 \%)$ by the total population $28154(\mathrm{Y})$.

$5 \mathrm{Y}-\mathrm{X}$ is the total households in the study area which are expected to have a valid response

6 Is the mean willingness to pay calculated from the open ended elicitation methods

7 Is mean multiplied by the number of total households which are expected to have valid response $\left(Z^{*}\right.$ Mean WTP) measured in ETB

EP 2018 (65) 1 (173-185) 
conservation. Thus, in estimating the value of environmental resource at household level, it is important to use contingent valuation method. The empirical findings on the determinants of WTP indicated that monthly income, educational level, total farm land holding, total family size, tropical livestock are key factors influencing the willingness to pay. Besides, the study estimated that there is a statistically significant and quantitatively non-negligible effect of perception on the households' WTP. Generally, the study leads us to conclude that understanding of socio-economic characteristics that significantly influenced households WTP is a necessary and first step to achieve groundwater conservation. Therefore, when designing groundwater project any policy maker should consider significant socio-economic factors for successful groundwater project at household level.

\section{Acknowledgements}

We would like to acknowledge the enumerators for the effort they made to collect survey data. Kombolcha agricultural office deserves special thanks for providing the necessary support throughout the period of this study.

\section{References}

1. Alemu, M. (2000). Valuation of community forestry in Ethiopia: A contingent valuation study of rural households. Environment and Development Economics, Beijer Institute of Ecological Economics, Royal Swedish Academy of Sciences. 5: 289-308pp.

2. Arrow, K., Solow R., Portney P.R., Leamer E. E., Radner R., and Schuman H. (1993). Report of the NOAA panel on contingent valuation, Federal Register. 58:4601-4614pp.

3. Central Statistical Agency (CSA), (1995). Report on land utilization, statistical bulletin 132, Central Statistical Authority, Addis Ababa (CSA), Ethiopia.

4. Emerton, L. and Bos, E. (2004). Value: counting ecosystems as an economic part of water infrastructure. IUCN, Gland, Switzerland.

5. Federal Democratic Republic of Ethiopia Population Census Commission (FDREPCC), (2008). Summary and statistical report of the 2007 population and housing census results. December 2008, Addis Ababa, Ethiopia.

6. Food and Agriculture Organization of the United Nations (FAO), (2003). Groundwater management. The search for practical approaches. Water Reports 25. Food and Agriculture Organization of the United Nations, Rome, Italy.

7. Haab, T.C. and McConnell, K.E. (2002). Valuing environmental and natural resources: the econometrics of non market valuation. Edward Elgar, Cheltenham U.K.

8. Johnston J, and Dindaro, J. (1997). Econometric methods. $4^{\text {th }}$ edition. New York.

9. Long, S. (1997). Regression models for categorical and limited dependent variable. 
10. Maddala, GS. (1997). Limited dependent and qualitative variables in econometrics. Cambridge University Press, 1-631 pp.

11. Maddala, G.S. (1992). Introduction to econometrics. $2^{\text {nd }}$ edition. Macmillan, Inc, University of Florida and Ohio state university, NewYork.

12. Malanson, G.P. (1993). Riparian landscapes. Cambridge University Press, Cambridge.

13. McDonald, JF. and Maffitt, A. (1980). The use of Tobit analysis. Rev. Econ. Stat., 62(2): 318-312pp.

14. Mitchell, R.C. and Carson, R.T. (1989). Using surveys to value public goods: the contingent valuation method. Resources for the Future, Washington, 463 p.

15. Morris, B L., Lawrence, ARL., Chilton, P J C., Adams, B., Calow R C. and Klinck, B.A. (2003). Groundwater and its susceptibility to degradation: a global assessment of the problem and options for management. Early Warning and Assessment Report Series, RS. 03-3. UNEP, Nairobi, Kenya.

16. Siebert, S., Burke, J., Faures, J. M., Frenken, K., Hoogeveen, J., D“oll, P., and Portmann, F.T. (2010). Groundwater use for irrigation - a global inventory. Hydrology and Earth System Sciences, 14, 1863-1880pp. 